\title{
THE PUZZLING PERSISTENCE OF DUAL FEDERALISM
}

\author{
ERNEST A. YOUNG
}

It may seem strange that, more than sixty years after Edward Corwin famously lamented "The Passing of Dual Federalism," this essay is part of a panel organized under the title "Against Dual Federalism." Accusations that the Court was trying to revive federalism were commonplace in the early years of the Rehnquist Court's "federalist revival." I argued more than a decade ago that these charges were misplaced, and that the actual doctrines that the Court was articulating in cases like United States v. Lopez ${ }^{2}$ and Printz $v$. United States ${ }^{3}$ could not really fit into the rubric of dual federalism. ${ }^{4}$ It is not that I'm surprised to find that my counsel has not been universally heeded; I have, after all, two teenage children. But I would think that by now the Court has made clear that it does not mean to impose particularly significant limits on the Commerce Clause, ${ }^{5}$ much less to bring back the entire dual federalist regime. Dual federalism remains hardly less dead than it was the day after the Court decided Wickard v. Filburn ${ }^{6}$ - a case that the Rehnquist Court repeatedly went out of its way to reaffirm and that the Roberts Court has not questioned.

Part of the problem is that not everyone means the same thing by "dual federalism." The legal literature on federalism uses the term to describe a particular model of allocating functions between the national government and the states, characterized by an 
attempt to define separate and exclusive spheres for national and state action. ${ }^{7}$ That model, I shall argue, is largely dead insofar as it operates as a check on national action; it survives, in a somewhat softer form, as a check on state action. But the latter aspect-dual federalism as a way of protecting national authority from incursions by the states-is not what generally concerns dual federalism's critics.

Those critics frequently equate "dual federalism" with any effort to impose constitutional federalism-based limitations on national authority. In the essay to which this commentary responds, for example, Sotirios Barber contrasts dual federalism with "Marshallian federalism," which he takes to be equivalent to the managerial "decentralization" model long advocated by Malcolm Feeley and Edward Rubin. ${ }^{8}$ This sort of position objects not only to a "separate spheres" model but to any model of federalism featuring guarantees of state autonomy that are constitutionally entrenched. Conflating concepts in this way, however, tends not only to confuse discussion but also to obscure the reasons that some approaches to federalism fail while others have more staying power.

This essay considers two ways in which notions of dual federalism persist. The first is the tendency of commentators to insist that the Supreme Court is bent on reviving strict dual federalist limits on national power, even when what the Court actually says and does makes rather clear that it is not. This persistence, in other words, is in the minds of the Court's critics-including Professor Barber, in his essay for this book. The second mode of persistence, however, is reflected in the Court's rhetoric and doctrine. That is the use of dual federalist notions to limit state power, by defining distinct and exclusive spheres of national regulatory activity. In preemption cases, for example, courts have found state law more readily preempted when it intrudes on a sphere of uniquely national concern, such as foreign relations or immigration.

I contend that the Court's critics are right to condemn dual federalism, but wrong to think that the Court has revived dual federalist limits on national power. Properly defined, "dual federalism" connotes separate and exclusive spheres of state and federal authority; it thus exists in contrast to other models of federalism, such as "cooperative" federalism, "collective action" federalism, 
and "process" federalism. All of these models may rely on principles of dual sovereignty that is, the broader notion that guarantees of state autonomy vis-à-vis the center should be constitutionally entrenched. While the Rehnquist and Roberts Courts have revived this broader principle, they have not attempted to define a separate sphere of state authority that the national government cannot enter.

Dual federalism died in the middle of the twentieth century because the Court found itself unable to draw determinate lines to define the exclusive sphere of state authority into which national power might not enter. That problem applies equally, however, to attempts to define and police an exclusive sphere of national authority; it thus plagues the contemporary cases in which courts have sought to keep states out of "uniquely federal" fields like foreign affairs, national banking, or immigration. But the linedrawing problem is not inherent in all efforts to protect other forms of state sovereignty; I thus reject Professor Barber's more general critique of dual sovereignty in all its forms. If we are to keep faith with our constitutional commitments, then federalism is not optional. As Jenna Bednar and William Eskridge have written, "[c]onstitutional law must make some sense of federalism."

\section{Some Definitions}

It will help to begin by defining some terms. Words like "dual federalism" are used in a variety of ways in the literature, and I do not mean to suggest that the definitions offered here are the only plausible ones. I do think that the conceptual distinctions drawn here matter, both theoretically and practically, and that whatever terms we happen to use, it will help to be more explicit about precisely what we mean.

\section{"Dual Federalism" versus "Dual Sovereignty"}

Alpheus Mason described "dual federalism" as contemplating "two mutually exclusive, reciprocally limiting fields of power-that of the national government and of the States. The two authorities confront each other as equals across a precise constitutional 
line, defining their respective jurisdictions." ${ }^{10}$ In his famous essay, Edward Corwin said that dual federalism entailed four "postulates":

[1.] The national government is one of enumerated powers only; 2 . Also the purposes which it may constitutionally promote are few; 3 . Within their respective spheres the two centers of government are "sovereign" and hence "equal"; 4 . The relation of the two centers with each other is one of tension rather than collaboration. ${ }^{11}$

Although Professor Corwin's postulates are somewhat more elaborate than Mason's definition, both statements share a common theme: Article I's limits on Congress's powers and purposes (postulates 1 and 2) define separate "spheres" of sovereignty for the federal and state governments (postulate 3), neither of which permits intrusion or activity by the other level of government (postulate 4). It is this notion of separate "spheres" or "enclaves" that has set dual federalism apart from other approaches to federalism for later generations of commentators. ${ }^{12}$

I want to distinguish dual federalism from dual sovereignty, although I acknowledge that the two terms are often used interchangeably. While dual federalism refers to a particular relationship between national and state authorities, I use "dual sovereignty" more generally to describe the Federalists' great innovation in political theory, which accommodated the separate authority of the states to classical political theory's requirement of a single "sovereign" in every polity by lodging that ultimate sovereignty in the American people. ${ }^{18}$ As Justice Souter has explained, "[T] he People possessing this plenary bundle of specific powers were free to parcel them out to different governments and different branches of the same government as they saw fit." ${ }^{14}$ Dual sovereignty thus means that the federal and state governments are "each sovereign, with respect to the objects committed to it, and neither sovereign with respect to the objects committed to the other."15

There is, of course, much disagreement about the precise meaning of what Robert Cover and Alex Aleinikoff called "the lawyer's disease of sovereignty." ${ }^{16}$ In our constitutional system, neither the national government nor the states possess the sort of unquestionable ultimate authority that the European theorists of the seventeenth and eighteenth centuries meant by "sovereignty."17 The 
Federalists thus used "dual sovereignty" as something of a debating point, co-opting the rhetoric of their opponents while advocating something completely different from the traditional unitary authority of the king in Parliament. ${ }^{18}$ And "sovereignty" is an even more contested term in our contemporary political environment, constantly under threat from policy concerns that disrespect territorial boundaries, broad conceptions of individual rights against government, the proliferation of international law and institutions, and the rise of complex intergovernmental institutional arrangements that blur traditional jurisdictional lines. ${ }^{19}$

Nonetheless, "dual sovereignty" does capture an important truth about American federalism: although nonfederal regimes may make the political choice to decentralize certain functions, the "sovereignty" of the states and the federal government means that at least some elements of the American allocation of authority are enforceable as a matter of legal right. This, for Edward Rubin and Malcolm Feeley, is the key distinction between "federalism" and "decentralization." 20 What "dual sovereignty" means in practice is that the federal arrangement is constitutionally entrenched-that is, it cannot be changed without constitutional amendment, which is of course very difficult to do. ${ }^{21}$

This element of entrenchment is critical to a wide range of definitions of federalism in both law and political science. Jenna Bednar, for example, defines a federal system as one meeting "three structural criteria"-geopolitical division according territory to each state unit, independent electoral bases of authority for state and national governments, and "policy sovereignty" for each level of government over some issues. ${ }^{22}$ Importantly, she presumes that each of these structural characteristics must be constitutionally entrenched. ${ }^{23}$ And the Supreme Court, of course, has long maintained that "the preservation of the States, and the maintenance of their governments, are as much within the design and care of the Constitution as the preservation of the Union and the maintenance of the National government. The Constitution, in all its provisions, looks to an indestructible Union, composed of indestructible States.' "24

Much of our federalism, of course, is not entrenched. As I have argued elsewhere, in many ways the most practically important boundaries between. national and state authority are set by federal 
statutes, agency regulations, or even defeasible judicial doctrines like the dormant Commerce Clause,${ }^{25}$ and perhaps it would be better if we spent more time talking about those arrangements and less time arguing about sovereignty. ${ }^{26}$ But as will be apparent, it remains an important point of division in debates about federalism whether any element of the federal arrangement is not subject to change through ordinary law.

Professor Barber seems to mean something like dual sovereignty when he says "dual federalism." He says, for instance, that "[d]ual federalism ... sees the Constitution as a collection of restraints on the national government, one kind of restraint being 'states' rights.'"27 This is hardly the only thing that dual sovereignty means; as I have argued elsewhere, the point of state sovereignty is not simply to limit national power but also to preserve the states' ability to provide beneficial regulation and governmental services to their citizens. ${ }^{28}$ But the key difference between dual sovereignty and the model of managerial decentralization proposed by Professors Feeley and Rubin is whether states do, in fact, have legally enforceable "rights" against the national authority. When Barber argues in favor of a national "authority to delegate and recall responsibility"29 vis-à-vis the states, he is arguing not only against dual federalism but against dual sovereignty as well.

The key point for present purposes is that "dual sovereignty" is a broader term than "dual federalism"; the former holds that ultimate authority is split between two types of governments in our political system, while the latter describes a particular model for what that division of authority might look like. Defining separate and exclusive spheres of state and national authority is one way to maintain a regime of dual sovereignty, but as I discuss in the next section, there are others as well. ${ }^{30}$ We might, for instance, focus on the institutional integrity of state governments themselves, or on the political mechanisms by which their interests are represented in the political process.

Professor Barber is thus right to argue that "the dual federalist view . . is an option to be weighed against competing options; it's not a conclusion compelled by constitutional language, logic, or history." ${ }^{31}$ But that is correct only in the limited sense in which I am using "dual federalism" here. That model is one among several that is consistent with "constitutional language, logic, [and] 
history." But to the extent that Barber is using "dual federalism" in a broader sense-that is, to connote a commitment to some meaningful principle of state sovereignty and a "limited [national] government" vis-à-vis the states - that commitment is not constitutionally optional. ${ }^{32}$ This is well-trod ground in the literature, and surely any assertion that the Constitution contains no such principle ought to grapple with the great weight of both jurisprudential and scholarly authority to the contrary. ${ }^{33}$

In rejecting any entrenched notion of dual sovereignty, Professor Barber relies on Madison's statement that "as far as the sovereignty of the states cannot be reconciled to the happiness of the people ... let the former be sacrificed to the latter." ${ }^{\prime 34}$ It is critical to remember, however, that Madison was arguing at a stage when the Constitution had not yet been adopted. After all, he said the same thing about the Constitution itself ("Were the plan of the Convention adverse to the public happiness, my advice would be, reject the plan.") and the Union ("Were the Union itself inconsistent with the public happiness, [my advice] would be, abolish the Union."). ${ }^{95}$ The people having made their choice to adopt the set of institutional arrangements offered in the Philadelphia draft (including a significant measure of state sovereignty), one can no longer repair directly to the public welfare as a reason to reject. state sovereignty without disregarding the binding force of the Constitution as law. ${ }^{36}$

This disagreement may simply reflect a difference (at least in emphasis) between my job, as a professor of law, and Professor Barber's, as a professor of political science. Law has a more limited scope than political science for arguments directly from general principles of public welfare. As Justice O'Connor observed in New York v. United States, “[o] ur task would be the same even if one could prove that federalism secured no advantages to anyone. It consists not of devising our preferred system of government, but of understanding and applying the framework set forth in the Constitution. ${ }^{\text {97 }}$ It is thus all well and good to argue that a system of nonentrenched decentralization would better pursue particularly national conceptions of liberty and other values, but lawyers and judges are limited by obligations of fidelity to the law that stand apart from these values. ${ }^{38}$ 


\section{Alternatives to Dual Federalism}

Dual federalism provided the model for our law of intergovernmental relations for roughly the first century and a half of our national existence. It died, for reasons I shall canvass shortly, in the New Deal revolution of 1937. And in truth, for much of the time since 1937 there has seemed to be little left of dual sovereignty either, as the Supreme Court has frequently seemed reluctant to enforce any constitutional limits on national authority. As I have already suggested, however, dual sovereignty-based limits can take a variety of forms that do not involve an attempt to define and police separate and exclusive spheres of state and national authority. I sketch some of those alternative models in this section. I begin, however, with the nationalist model that Professor Barber appears to advocate.

\section{Managerial Decentralization or "Marshallian Federalism"} It is a little hard to know for sure what Professor Barber means by "Marshallian federalism." He offers a definition at the outset of his essay: "Marshallian federalism holds that when the nation's government is pursuing authorized constitutional ends it may freely disregard the reserved powers of the states."39 But that formulation is perfectly consistent with "dual federalism" as it has been described in the literature and practiced by the Court; everything turns, of course, on what "constitutional ends" the national government is "authorized" to pursue. Dual federalism held that those ends are confined to a distinct sphere of governmental activity, but because that sphere is exclusive, the states could have no reserved powers to get in the way. If Barber's target is simply the notion that a state may interpose its own law to block the effect of a national law that falls within Congress's enumerated powers, then he is truly pushing on an open door.

It is clear from Professor Barber's discussion, I think, that he means something more restrictive than this. Throughout his essay, he decries the notion of enforceable "states' rights" and urges that the national authority should be able to pursue national ends-like liberty or democracy-by calibrating the allocation of power between national and state institutions as the circumstances 
dictate. ${ }^{40}$ The implicit assumption seems to be that the national government will always be "better" on issues of democracy than those of the states. While that is certainly sometimes true, it has not always been the case. ${ }^{41}$ Recognizing this reality, Alexander Hamilton (not exactly a states' righter) emphasized the need for both state and national governments to serve as checks on one another:

Power being almost always the rival of power, the general government will at all times stand ready to check the usurpations of the state governments, and these will have the same disposition towards the general government. ... If [the people's] rights are invaded by either, they can make use of the other as the instrument of redress. ${ }^{42}$

Professor Barber, by contrast, would dispense with the states' checking function. His federalism, like Professors Rubin and Feeley's decentralization, "is a managerial concept," not a matter of constitutional principle; Barber's polity, like theirs, is "hierarchically organized and the leaders at the top or center have plenary power over the other members of the organization." 43 This view, whatever its merits, is the antithesis of dual sovereignty.

More fundamentally, Professors Rubin and Feeley have argued that "the point of federalism"-as opposed to decentralization"is to allow normative disagreement amongst the subordinate units so that different units can subscribe to different value systems." 4 But it is the very possibility of legitimate normative disagreement that Professor Barber seems to reject:

Locating constitutional authority in one place, instead of thirteen or fifty, is necessary because the decision to delegate discretion or recall it must flow from one judgment regarding ends and means. Liberty is best served if the best feasible conception of liberty is served. Some authority has to judge among competing conceptions in particular situations. ... One institution is obviously superior to many because to be effective many institutions would have to concur in one conclusion or one consistent set of conclusions regarding means and ends. ${ }^{45}$

One wonders if the American political system is really set up to render such a unitary conception of the good, even if we disregard the states. Not only is Congress a "they," not an "it," ${ }_{46}$ with notoriously multifarious and discordant conceptions of the good, but 
the national separation of powers envisions perpetual competition between legislative, executive, and judicial institutions that may each harbor its own conceptions of liberty, democracy, or good policy. In any event, when Barber argues that our constitutional structure entails "a substantive commitment-an overarching and controlling view of the good life within which subordinate views must find a place as contributing views," ${ }^{77}$ he plainly takes issue not only with the narrow model of "dual federalism" but with any model that envisions constitutional restraints on national authority vis-à-vis the states. That puts Barber squarely in the Rubin and Feeley camp.

Professor Barber describes his view as "Marshallian federalism," but the position he describes is plainly not John Marshall's federalism. Barber provides no evidence for his claim that "Marshall's constitutionalism would commit the nation to a more-or-less specific way of life." 48 Other students of Marshall have concluded that "a constitution . . . is made for people of fundamentally differing views." 49 More to the point, Chief Justice Marshall repeatedly insisted that the Constitution limits national power. In $\mathrm{McCulloch}$, for example, Marshall warned that "[s]hould Congress, in the execution of its powers, adopt measures which are prohibited by the constitution; or should Congress, under the pretext of executing its powers, pass laws for the accomplishment of objects not entrusted to the government; it would become the painful duty of this tribunal . . . to say that such an act was not the law of the land." ${ }^{50}$ And in Gibbons, Marshall went so far as to articulate not simply dual sovereignty but the "separate spheres" notion of dual federalism typical of his age:

The genius and character of the whole government seem to be, that its action is to be applied to all the external concerns of the nation, and to those internal concerns which affect the States generally; but not to those which are completely within a particular State, which do not affect other States, and with which it is not necessary to interfere, for the purpose of executing some of the general powers of the government. The completely internal commerce of a State, then, may be considered as reserved for the State itself. ${ }^{51}$

It is certainly true that the thrust of the Great Chief Justice's federalism decisions was to carve out a place for the fledgling 
national government and rein in the centrifugal impulses of the states. But that hardly means that Marshall stood ready to abandon all constitutional constraints on national power, and one can readily imagine that he would be shocked at the extent of national authority today. It is no coincidence that Rubin and Feeley, upon whom Barber seems to pattern his position, bill their managerial concept of decentralization as a modern remedy for an outdated "neurosis." Certainly there is nothing traditional, let alone Marshallian, about it.

\section{Cooperative (and Uncooperative) Federalism}

Cooperative federalism eschews the separate spheres of dual federalism and embraces the reality that, in modern America, "virtually all governments are involved in virtually all functions. ... [T] here is hardly any activity that does not involve the federal, state, and some local government in important responsibilities." ${ }^{52}$ Philip Weiser has explained:

In contrast to a dual federalism, cooperative federalism envisions a sharing of regulatory authority between the federal government and the states that allows states to regulate within a framework delineated by federal law. In particular, modern regulatory programs put in place across a variety of fields ranging from nearly all environmental programs to telecommunications regulation to health care ... all embrace a unified federal structure that includes a role for state implementation. ${ }^{53}$

Under cooperative federalism, then, national authorities do not merely possess concurrent regulatory jurisdiction; the actual activity of each government is closely integrated with that of the other ${ }^{54}$

Advocates of constitutional limitations on national authority have often regarded cooperative federalism with suspicion, seeing the subordinate role of state officials within federal regulatory schemes as reflecting a "concentration of political powers in the national government." ${ }^{55}$ Larry Kramer has pointed out, however, that in a cooperative system, " $[t]$ he federal government needs the states as much as the reverse, and this mutual dependency guarantees state officials a voice in the process. ${ }^{56} \mathrm{He}$ concedes that this is "[n]ot necessarily an equal voice: because federal law is supreme and Congress holds the purse strings, the federal government is 
bound to prevail if push comes to shove. But federal dependency on state administrators gives federal officials an incentive to see that push doesn't come to shove, or at least that this happens as seldom as possible, and that means taking state interests into account." ${ }^{57}$ More recently, Jessica Bulman-Pozen and Heather Gerken have taken this insight and run with it to develop a model of "uncooperative federalism," which "occurs when states carrying out the Patriot Act refuse to enforce the portions they deem unconstitutional, when states implementing federal environmental law use that power to push federal authorities to take a new position, or when states relying on federal funds create welfare programs that erode the foundations of the very policies they are being asked to carry out." ${ }^{58}$ This phenomenon, they note, occurs "in such varied arenas as immigration, healthcare, and education. In each of these fields, states use regulatory power conferred by the federal government to tweak, challenge, and even dissent from federal law." 59

One may think of "uncooperative federalism" as a particular form of Morton Grodzins's general idea of "decentralization by mild chaos. ${ }^{\text {"60 }}$ Despite the absence of clear lines demarcating state and national power, the reality of multiple power centers and the myriad opportunities to exert influence guarantee meaningful checks on central authority. Thus described, however, uncooperative federalism seems like a practical consequence of particular institutional forms of managerial decentralization, rather than an alternative model of dual sovereignty. Nonetheless, at least some approaches to cooperative federalism retain a place for sovereignty.

In particular, the anticommandeering doctrine imposes an important constitutional constraint on Congress's ability to enlist the states as implementers of federal law. That doctrine holds that Congress may not require the legislative and executive institutions of state government to enact legislation pursuant to federal directives, enforce the requirements of federal law, or otherwise serve as the instruments-as opposed to the objects-of federal regulation. ${ }^{61}$ Because Congress may not simply command such implementation, it must secure the states' consent by making participation in the federal scheme attractive. Likewise, constitutional constraints on Congress's authority to condition grants of federal 
monies on state acquiescence in federal mandates ${ }^{62}$ ensure that states retain some enforceable rights against the national government even in cooperative federalism schemes. The presence of these constraints ensures that some aspects of the federal structure remain constitutionally entrenched, even within a cooperative federalism scheme.

\section{Subsidiarity or Collective Action Federalism}

A second model of dual sovereignty reasons from the underlying values that a federal system is meant to serve. Donald Regan has argued, for example, that "in thinking about whether the federal government has the power to do something or other, we should ask what special reason there is for the federal government to have that power. What reason is there to think the states are incapable or untrustworthy?"63 Professor Regan's approach bears a strong family resemblance to the European Union's principle of "subsidiarity," under which "the Community shall take action . . only if and in so far as the objectives of the proposed action cannot be sufficiently achieved by the Member States and therefore by reason of the scale or effects of the proposed action, be better achieved by the Community." ${ }^{64}$ The Member States of the EU added subsidiarity to the EU's governing treaties as a result of fears that the original documents - which like the American Constitution relied on specific enumerations of the EU's powers-were insufficiently protective of Member State prerogatives. ${ }^{65}$

In this country, the most extended and thoughtful attempt to realize a subsidiarity-type approach to federalism is the recent work of Robert Cooter and my colleague Neil Siegel. Professors Cooter and Siegel read the Constitution's power grants to Congress in Article I, Section 8 as embodying a single coherent principle of "collective action federalism." 66 In their view, "the clauses of Section 8 ... authoriz[e] Congress to tax, spend, and regulate when two or more states face collective action problems. Conversely, governmental activities that do not pose collective action problems for the states are 'internal to a state' or 'local.' "67 Congress would therefore be able to legislate to solve a collective action problem whether or not the legislation regulated commercial activity; on the other hand, even regulation of buying and selling might fall outside Congress's power if it did not respond to some difficulty 
preventing resolution of the problem through action by individual states.

The principal difficulty with subsidiarity-based approaches is that they tend to collapse the constitutional question ("What does the Constitution permit?") into the policy question ("What would it be desirable for Congress to do?"). As numerous commentators have noted, this makes subsidiarity inquiries particularly difficult for courts, which ordinarily depend for their legitimacy on the supposition that they simply enforce the law without secondguessing Congress's policy judgments-that they exercise "judgment," not "will," in Alexander Hamilton's memorable account. ${ }^{68}$ This difficulty has bedeviled efforts to enforce subsidiarity as a constitutional principle in the European Union, ${ }^{69}$ and commentators (including this one) have raised similar concerns with efforts to develop a similar approach on this side of the pond. ${ }^{70}$

One may also worry that this logic, taken too far, would leave precious little to the States. As Morton Grodzins pointed out long ago, "[I]nequities of state resources, disparities in educational facilities and results, the gap between actual and potential educational services, and, above all, the adverse national consequences that might follow long-term inadequacies of state-local control would almost certainly, if the choice had to be made, establish education as the exclusive concern of the national government." ${ }^{.11}$ One suspects that similar arguments could be made in almost any field if one's conception of a collective action problem is sufficiently broad. And to the extent that courts defer to legislative judgments in order to avoid crossing the line into policy making, they will be leaving the foxes in charge of the henhouse. ${ }^{72}$

The important point for present purposes, however, is that subsidiarity or collective action federalism represents a distinct model of dual sovereignty from dual federalism. It retains an aspect of sovereignty because, according to the model's proponents, the notion that some collective action problem must exist to justify national action is an interpretation of Article I, Section 8-that is, it is an entrenched part of the Constitution. National action without such a justification would thus be unconstitutional. And yet collective action problems-or their absence-may occur in virtually any area of regulatory concern. This approach thus does not yield the separate and exclusive spheres of regulatory activity 
that characterized dual federalism. ${ }^{73}$ Some aspects of criminal law, or environmental law, or any other field will raise collective action problems, while others may not. The justification for any given national endeavor must be judged on its own merits, regardless of the field in which it occurs.

\section{Process Federalism}

Process federalism has its unlikely origins in Garcia v. San Antonio Metropolitan Transit Authority ${ }^{74}$ - a case that William Van Alstyne decried as the "second death of federalism." J5 Justice Blackmun's majority opinion in Garcia asserted that "the fundamental limitation that the constitutional scheme imposes on the Commerce Clause to protect the 'States as States' is one of process rather than one of result. Any substantive restraint on the exercise of Commerce Clause powers must find its justification in the procedural nature of this basic limitation, and it must be tailored to compensate for possible failings in the national political process rather than to dictate a "sacred province of state autonomy." "76 Process federalism thus eschews the exclusive subject matter spheres of state and national authority that characterize dual federalism. Instead, it relies on the political and institutional structure of the national government itself to preserve the autonomy of the states.

As Professor Van Alstyne's memorable phrase suggests, Garcia was initially either lamented or hailed as the end of the line for state sovereignty. ${ }^{77}$ Both friends and foes of constitutional limitations on national authority assumed that the abandonment of substantive limits really connoted an abandonment of any limits at all. This turned out not to be true, however. Just as John Hart Ely has shown that a process-based theory of individual rights can provide a powerful basis for judicial review, ${ }^{78}$ so too process federalism has turned out to provide vigorous protection for state autonomy. ${ }^{79}$ In both instances, process theory simply shifts the focus from the substantive character of governmental action to the institutional process by which the government acts.

Professor Ely's idea was that our system of government ordinarily safeguards individual liberties through the political process of democratic representation; courts play a supporting role, stepping in whenever there is reason to believe that the ordinary democratic process has become skewed (e.g., through restrictions on 
political participation) or particular groups have been systematically excluded (e.g., racial minorities) ${ }^{80}$ Process federalism similarly builds on Herbert Wechsler's insight (derived in turn from James Madison and John Marshall) that the first-line protection for federalism in our governmental system is the political representation of the states in Congress. ${ }^{81}$ Building on Wechsler, other scholars have stressed the role of political parties as well as more particular institutional features, such as the role of state legislatures in redistricting for federal congressional districts. ${ }^{82}$

Other process federalists have emphasized the procedural protections that states derive from the many impediments to federal lawmaking. As Brad Clark has explained, "The lawmaking procedures prescribed by the Constitution safeguard federalism in an important respect simply by requiring the participation and assent of multiple actors. These procedures make federal law more difficult to adopt by creating a series of 'veto gates.' ... [T] he imposition of cumbersome federal lawmaking procedures suggests that the Constitution reserves substantive lawmaking power to the states and the people both by limiting the powers assigned to the federal government and by rendering that government frequently incapable of exercising them." 83

Supreme Court doctrine has reinforced these political and procedural safeguards of federalism in a variety of ways. Most important, the Court has constructed an array of "clear statement" rules of statutory construction, triggered whenever Congress acts in a way that implicates the prerogatives and/or autonomy of the states. These rules require a clear expression of Congress's intent before a federal statute may be construed to regulate the public functions of state governments, ${ }^{84}$ impose financial liability on the states, ${ }^{85}$ abrogate state sovereign immunity, ${ }^{86}$ impose conditions on the grant of federal funds to state governments, ${ }^{87}$ or preempt state law. ${ }^{88}$ While these canons of statutory construction are not uncontroversial, ${ }^{89}$ they are best understood as an extension of the underlying federalist constitutional principles. ${ }^{90}$ They enhance the political safeguards of federalism by requiring proponents of federal laws affecting the states to put the states' defenders in Congress on notice; they enhance the procedural safeguards by adding an additional drafting hurdle that legislation implicating state autonomy must surmount. As a practical matter, it is fair to say that 
the Court's clear statement cases have preserved a great deal more state autonomy than its largely symbolic efforts to police the substantive boundaries of the Commerce Clause.

Similarly, one can best understand the anticommandeering doctrine of New York and Printz ${ }^{91}$ as a tool of process federalism. Federal commandeering - that is, the power of Congress to require state institutions to implement federal law-allows national authorities to foist many of the costs of national action onto state institutions. These include financial costs, because states must bear the costs of implementation without any requirement that Congress reimburse them, and political costs, because state officials often become the public face of unpopular federal programs (like nuclear waste disposal in New York and limits on gun purchases in Printz) ${ }^{92}$ The anticommandeering doctrine does not, in practice, prevent the states from implementing federal law; as I have already said, cooperative federalism arrangements are pervasive in our system. But because the doctrine requires Congress to solicit rather than command state implementation, the states can insist on compensation for their expenses and refuse to participate in the most unpopular programs. ${ }^{93}$ This measure of independence from outright federal control may also enhance the ability of state administrators within cooperative federalism regimes to use the administrative process to influence and/or resist federal policy.

Professor Barber makes some very odd assertions about process federalism; for instance, he claims that the process federalist "will eventually claim that the only good anyone can really know is pleasure centered on the individual human body." ${ }^{94}$ I suspect this conclusion would come as a major surprise to scholars (like this one) who have long advocated process federalism. As I have already suggested, it may be more constructive to engage the arguments that process federalists actually make-Barber's essay is devoid of citation to any work that actually discusses process federalism-than to theorize about what arguments process federalists must make. In any event, what actually distinguishes process-based from dual federalism models is simply the former's focus on the political and procedural dynamics by which the states participate in the national political process and federal actors construct supreme federal law. Get those dynamics right, the process federalist contends, and 
one need not worry about whether particular national initiatives intrude into some protected state sphere of authority.

Immunity Federalism

A final model is rarely discussed distinctively in the literature but is quite prominent in the Court's case law. That model is "immunity federalism," which seeks to protect the institutions of state government themselves from being subjected to or held accountable for violations of national law. ${ }^{95}$ Dual federalism emphasized affirmative authority to regulate-that is, to prescribe legal rules governing the conduct of nongovernmental actors. It was thus concerned, for example, with whether national or state authorities get to control the legal regime governing public education or immigration. Immunity federalism, by contrast, is relatively unconcerned with affirmative regulatory jurisdiction; it sets no limits on the scope of national regulatory authority over private individuals. This model concerns national regulation solely as it impacts the institutions of state governments themselves. A good example is thus National League of Cities $v$. Usery, ${ }^{96}$ which did not challenge Congress's authority to regulate the wages and hours of all privately employed workers in the United States but did restrict its right to apply those regulations to state governmental employees.

The most obvious flowering of immunity federalism has, of course, occurred in the Supreme Court's cases construing the sovereign immunity of states from lawsuits by private individuals and corporations. More than a century ago, in Hans v. Louisiana,$^{97}$ the Court construed the scope of this immunity to extend significantly beyond the text of the Eleventh Amendment, which had generally been considered the source of state sovereign immunity. ${ }^{98}$ Much more recently, in Seminole Tribe v. Florida, ${ }^{99}$ the Court held that Congress may not subject states to suit when they violate federal law by enacting statutes that "abrogate" the states' immunity, at least when Congress acts pursuant to its Article I powers. Subsequent decisions have extended this principle to suits in state courts and before federal administrative agencies, notwithstanding the limitation of the Eleventh Amendment's text to "the judicial power of the United States," 100 and an impressive line of cases has narrowly construed Congress's exceptional power to abrogate state sovereign immunity when it acts pursuant to its power to enforce the 
Reconstruction Amendments. ${ }^{101}$ The important point about all of this is that state sovereign immunity does not protect a single square inch of state regulatory "turf" from federal intrusion; it simply exempts the states from (one means of) accountability when they themselves violate federal law. ${ }^{102}$

A final, less frequently remarked instance of immunity federalism appears in the Court's habeas corpus jurisprudence. Although habeas has recently played a prominent role in the national War on Terror as a remedy for detention by national executive authorities, by far its most common use is as a vehicle for collateral review of state criminal convictions for compliance with the procedural requirements of federal constitutional law. ${ }^{103}$ Habeas corpus is thus another mechanism for holding states accountable when they violate federal law, and the extensive jurisprudence of the Burger, Rehnquist, and Roberts Courts limiting the scope of federal habeas review is thus another instance of immunity federalism. ${ }^{104}$ (In this, it is worth noting, the Court has been encouraged and even surpassed by Congress itself, which passed extensive restrictions on habeas as part of the Antiterrorism and Effective Death Penalty Act in 1996. $)^{105}$ Importantly, the number of state sovereign immunity and habeas corpus decisions by the Supreme Court over the course of the "federalist revival" dwarfs the number of cases considering substantive limitations on Congress's powers.

* * *

The point of this survey of the multifarious models of contemporary federalism doctrine is to show that dual federalism and managerial decentralization are not the only choices for allocating authority between the national government and the states, and that dual sovereignty may be maintained in other ways than by defining separate and exclusive spheres of state and national authority. These models, like any analytical construct imposed upon an unruly and variegated set of real-world decisions and structures, are vague around the edges, often overlap, and indeed may not be mutually exclusive; process federalism, for example, can be a valuable tool to preserve some measure of state sovereignty in an institutional structure of cooperative federalism. The important point is that there is a tendency to assume that any rule of law that accords some measure of sovereignty to state governments is an 
instance of "dual federalism," but we should resist that tendency. It is of course a prerogative of scholars to define terms any way that we want, but we lose valuable analytical distinctions when we lump together approaches that are in fact quite different.

\section{The Current State of Play}

Having sketched out the dual federalist model and its competitors, we are in a position to evaluate which of these models best reflects the current state of affairs in intergovernmental practice and constitutional doctrine. My principal contention is that, although scholars and sometimes dissenting judges often worry that the Supreme Court is about to revive dual federalism, it has not in fact done so and is extremely unlikely to do so in the future. Current doctrine and practice instead reflect a blend of managerial decentralization, cooperative federalism, and process federalism.

The Court's restraint, however, has sometimes been unidirectional-that is, it has generally rejected dual federalism in its cases limiting national power, but has often embraced it in its cases limiting state power. These cases tend to define an exclusive sphere of federal authority-most often involving foreign affairs or immigration, but sometimes more prosaic fields like banking-and presumptively exclude state regulatory activity touching on those fields. Neither the results nor the reasoning is categorical, and the Court has actually left far more room for state activity within these presumptively federal spheres than it might have in the heyday of dual federalism. Nonetheless, these cases represent a troubling movement back in the direction of the old unworkable doctrine.

\section{Dual Federalism Is Dead}

Dual federalism dominated constitutional law for roughly a century and a half. Beginning in cases like Gibbons, the Court sought to define separate and exclusive spheres of state and federal authority. Because Congress was not eager to exercise its affirmative regulatory powers for most of the nineteenth century, most of the cases involved challenges to state regulation under either the dormant Commerce Clause or the judge-made "general common law"-both of which effectively forbade state intrusion into the 
"national" sphere of interstate commerce. ${ }^{106}$ As federal regulatory efforts increased around the turn of the twentieth century, the courts began to employ dual federalism to restrict those efforts, either by construing federal statutes narrowly to avoid intruding on state spheres of authority ${ }^{107}$ or simply by striking them down. ${ }^{108}$

The Court upheld as many statutes as it struck down, however, even during the infamous Lochner era. It was thus forced to draw increasingly fine distinctions between goods that were in the "stream of commerce" and those that were not, or between "direct" and "indirect" effects on the interstate market. ${ }^{109}$ The advent of the New Deal put increasing pressure on these distinctions, and the Court's eventual capitulation to the national regulatory state in 1937 ultimately swept them away. In $N L R B v$. Jones $\mathcal{E}^{2}$ Laughlin Steel Corp.,${ }^{110}$ the Court signaled that it would no longer distinguish between phases of the production cycle-that is, between regulation of "manufacturing" or "employment," which had heretofore been a state sphere, and the actual buying, selling, or transport of goods. And in Wickard $v$. Filburn, ${ }^{111}$ decided five years later, a unanimous court held that Congress may regulate even individual activities with a minimal impact on commerce, so long as in the aggregate that class of activity would have a substantial effect on the interstate market. By 1950, Edward Corwin could say that the "entire system of constitutional interpretation" embodied in dual federalism lay "in ruins." 112

The question, of course, is whether the "federalist revival" of the Rehnquist Court (and possibly the Roberts Court) has revived dual federalism. Professor Barber and a surprising number of other critics seem to think that it has. ${ }^{113}$ Barber fears a "recrudescence of state sovereignty" under which "the states' rights bloc on the Rehnquist Court [has] affirmed the contract theory [under which the states are "separate and independent sovereigns who could nullify unconstitutional national acts and even withdraw from the union"] and voided numerous national acts in the name of 'state sovereignty." "114 There are, however, very few citations. The only case from this period that Barber actually mentions by name is U.S. Term Limits, Inc. $v$. Thornton, ${ }^{115}$ which he takes to represent "an endorsement of the contract theory by four members of the Rehnquist Court." 116 One can quibble about whether even that is really true-Term Limits grappled with the Framers' theory of 
representation in order to construe whether the Constitution's Qualifications Clauses for members of Congress were exclusive, not the limits of Congress's regulatory powers, and invoking the contract theory for the former purpose is quite different from using it to determine the latter. ${ }^{17}$ But putting that aside, Justice Thomas's opinion in Term Limits was a dissent. It struck down nothing and has not been an important source of guidance for any of the decisions in which the Court has struck down federal statutes. Moreover, even Justice Thomas has made clear that he has a sophisticated theory of the Supremacy Clause (which was not at issue in Term Limits) that allows broad scope for federal authority. ${ }^{118}$

The best cases for a dual federalist revival would be United States v. Lopez, ${ }^{119}$ in which the Court struck down the federal Gun Free School Zones Act as exceeding Congress's authority under the Commerce Clause, and United States v. Morrison, ${ }^{120}$ in which the Court similarly invalidated the private civil suit provision of the federal Violence Against Women Act. Lopez was certainly exciting, in the sense that it was the first time that the Court had struck down a federal statute under the Commerce Clause since the New Deal revolution, and many of us took Morrison as confirming that Lopez was not a sport and the Court was, in fact, serious about limiting national power. Neither of these cases, however, amounted to a return to the traditional doctrine of dual federalism. As I have discussed in more detail elsewhere, ${ }^{121}$ both cases turned on whether Congress was regulating an act that was "commercial" in nature. The Lopez Court explicitly reaffirmed Wickard v. Filburm ${ }^{122}$ and the rest of its post-New Deal jurisprudence, ${ }^{123}$ and it defined "commercial" activity so broadly that there are no substantive fields of regulatory concern in which many, if not most, activities will not be subject to federal regulation. ${ }^{124}$ Equally important, both Lopez and Morrison made clear that the Court had abandoned the distinction-initially drawn by John Marshall in Gibbons-between commerce "among the several states" and "the exclusively internal commerce of a State." ${ }^{25}$ The Rehnquist Court, in other words, was significantly less committed to dual federalism than is "Marshallian federalism."

In any event, the excitement over Lopez and Morrison was shortlived. Five years after Morrison, in Gonzales v. Raich, ${ }^{126}$ the Court affirmed Congress's power to regulate the medicinal use of homegrown marijuana, notwithstanding the fact that the marijuana in 
question had been neither purchased nor transported across a state line. And the Court considered it legally irrelevant that California had enacted a regulatory scheme licensing and regulating the use of marijuana for medicinal purposes. ${ }^{127}$ Justice Kennedy joined Justice Stevens's majority opinion, signaling that he was unwilling to find that any significant federal regulatory program lacked the requisite link to commercial activity. And, perhaps most damaging of all to any hopes of a return to dual federalism, Justice Scalia wrote a concurrence embracing a broad view of the Necessary and Proper Clause, which would allow Congress' to regulate even noncommercial activity so long as it bears some relation to a commercial activity that Congress can reach. ${ }^{128}$

The Court's recent decision on the Patient Protection and Affordable Care Act (PPACA) complicates the picture somewhat, but none of the justices endorsed a return to dual federalism. In National Federation of Independent Business $v$. Sebelius $(N F I B),{ }^{129}$ a majority of the Court upheld the act's "individual mandate" that all persons must buy health insurance under the taxing power, ${ }^{130}$ but a different majority opined that the mandate did exceed the limits of Congress's commerce power. ${ }^{131}$ That portion of the opinion-the most relevant for our purposes-did not suggest that health care is somehow an exclusively state sphere of regulation. Rather, the Chief Justice and the four dissenters agreed that the Commerce Clause does not permit Congress to regulate pure inactivity-that is, the decision not to buy health insurance. ${ }^{132}$ This is an important holding, both because the PPACA is an important statute and because it reverses the post-Raich impression that the Court might be ready to abandon Lopez and Morrison. But there are not many such mandates in federal law, and the Court's holding at most places a particular regulatory tool off limits rather than isolating a substantive field of regulation as beyond federal competence. ${ }^{133}$

Finally, when Professor Barber refers to "numerous national acts" that the Rehnquist Court has "voided ... in the name of 'state sovereignty," "134 he can only be referring to the Court's admittedly impressive string of holdings under the Eleventh Amendment doctrine of state sovereign immunity. I agree that these cases are wrongly decided and that they represent an unhelpful focus on state sovereignty rather than state regulatory autonomy. ${ }^{135}$ But they hardly represent a return to dual federalism. ${ }^{136}$ First, these cases 
simply invalidate provisions of the relevant federal acts that subject the states to suits by private individuals for money damages; they do not invalidate the underlying substantive requirements of the relevant acts, which continue to bind even the states. It is thus impossible to say that these decisions carve out any exclusive sphere of state authority; they simply restrict the remedies available when states violate the law. Second, these remedial restrictions are radically incomplete: they do not bar suits against state officers for prospective relief or for damages when the officers are sued in their individual capacity. Nor do they bar even suits against the state itself for damages when the United States is the plaintiff or when Congress, through its power of the purse, induces the states to waive their immunity. All these "workarounds" significantly minimize the practical significance of state sovereign immunity. ${ }^{137}$ Finally, the Court seems to be in substantial retreat from these holdings, having upheld congressional provisions abrogating state sovereign immunity in several recent decisions. ${ }^{138}$

Sixty years later, Professor Corwin is still right: dual federalism lies "in ruins." What we have instead is a complicated and not always coherent set of doctrines emphasizing process federalism (particularly in the Court's "clear statement" rules of statutory construction), ${ }^{139}$ an important but narrow rule against "commandeering" state institutions operating within cooperative federalism regimes, and (perhaps) even narrower rules prohibiting use of the commerce power to reach pockets of activity that either have no relation to commerce (Lopez and Morrison) or do not even amount to activity at all $(N F I B)$. The Necessary and Proper Clause, moreover, looms as a congenial catchall power in doubtful cases. ${ }^{140}$ There are interesting debates to be had concerning whether the Court's current doctrines-both permissive and restrictive-are legitimate, whether they go far enough, and even whether the courts are well suited to balance national and state authority. But it will help, in approaching any of these questions, to appreciate how much the ground has shifted since 1937.

\section{Long Live Dual Federalism?}

Both the Court and the commentators have done their best to inter dual federalism, and for the most part they have succeeded. 
But in some areas, dual federalism dies hard. To paraphrase Justice Scalia's famous description of the Lemon test in the Court's Establishment Clause jurisprudence: "Like some ghoul in a latenight horror movie that repeatedly sits up in its grave and shuffles abroad, after being repeatedly killed and buried, [dual federalism] stalks our [federalism] jurisprudence once again." ${ }^{141}$ Only this time, it is frightening the proponents of state regulatory activity in fields where the national government has traditionally played a significant role. The tendency to revive dual federalist notions of exclusive national power has been most pronounced in the area of foreign relations law, including recent controversies of state efforts to ratchet up the enforcement of federal laws regulating undocumented aliens. But a similar, if more low-profile, trend has surfaced in the Court's statutory preemption cases. The Court would do better to bring each area into line with its more general federalism doctrine by giving these dual federalist tendencies a speedy quietus.

I wrote in 2001 that the Court seemed to be clinging to a dual federalist view in some of its foreign affairs cases by applying a more vigorous rule of preemption. ${ }^{142}$ In Crosby v. National Foreign Trade Council, ${ }^{143}$ for example, the Court struck down a Massachusetts law limiting state dealings with companies doing business in Burma, notwithstanding the absence of any explicit federal statutory language preempting such state laws. More recently, the Court seemed to extend Crosby in American Insurance Association v. Garamendi, ${ }^{144}$ which struck down a California law requiring insurance companies to disclose any connection they might have to Holocaust insurance policies, again in the absence of explicit preemptive language. Both decisions strongly suggested that the states simply had no place regulating the business of foreign relations.

Likewise, in the last year, much of the debate concerning state governmental initiatives to regulate illegal immigration has taken a decidedly dual federalist turn. In particular, the Ninth Circuit's ruling striking down Arizona's restrictive immigration law strongly suggested that states are simply incapable of regulating immigration-this is an exclusively federal field. ${ }^{145}$ On review in Arizona v. United States, however, the Supreme Court took a more equivocal position. On the one hand, it suggested that im- 
migration must be a federal sphere by emphasizing that "foreign countries concerned about the status, safety, and security of their nationals in the United States must be able to confer and communicate on this subject with one national sovereign, not the 50 separate States."146 On the other, Justice Kennedy's majority opinion also acknowledged that the states have a role to play in this field, noting that " $[\mathrm{t}]$ he pervasiveness of federal regulation does not diminish the importance of immigration policy to the States." 147 The Court's actual analysis stressed ordinary preemption principles, not doctrines of federal exclusivity, ${ }^{148}$ although it does seem fair to say that the Court applied those doctrines with a propreemption thumb on the scale.

Similar echoes of dual federalism can be found in the Court's other preemption cases, where the Court often emphasizes traditional fields of state or federal regulatory authority. Rick Hills has asserted that "the Roberts Court's [preemption] decisions seem to follow a traditional script of dual federalism-that is, carving out separate spheres for state and federal governments and enforcing norms of mutual non-interference between these spheres."149 A good example is United States $v$. Locke, ${ }^{150}$ in which the Court held that federal law preempted Washington state regulations governing oil tanker safety in Puget Sound that went further than federal requirements. The Court emphasized that maritime safety, which implicated international obligations as well as domestic law, was a traditionally federal field and thus refused to apply any presumption against a preemptive reading of the statute. Locke illustrates not only the backward glance to dual federalism but also the trouble inherent in that glance; after all, it is equally easy to characterize Locke as a case about safeguarding the natural resources of the state $\rightarrow$ a traditional state sphere. ${ }^{151}$

In any event, efforts to revive dual federalism even in these limited nationalist enclaves blink reality. As Grodzins has pointed out, "[f]oreign affairs, national defense, and the development of atomic energy are usually considered to be exclusive responsibilities of the national government. In fact, the state and local governments have extensive responsibilities, directly and indirectly, in each of these fields." ${ }^{52}$ This has only become more true in the decades since Grodzins wrote. ${ }^{153}$ In our increasingly globalized world, 
no governmental actor-including states and even localities-can avoid interacting with the rest of the world in a way that implicates national foreign policy. ${ }^{154}$

This nationalist version of dual federalism should not be overstated, however. All the cases I have mentioned are statutory construction cases, not efforts to draw hard constitutional lines in the sand, and cases like Arizona seem to leave significant room for state regulation even in areas of federal primacy. Moreover, there are plentiful counterexamples. Just this past term, for instance, the Court upheld a different Arizona law providing for penalties on employers who employ undocumented aliens. ${ }^{155}$ The Court not only found the law not preempted; it also went out of its way to say that the law did not implicate any unique field of federal authority. We are far from a revival of dual federalism, but some of the cases in these areas are worrisome nonetheless.

\section{Is Dual Federalism "Self-Defeating"?}

This final section considers two distinct critiques of dual federalism. The first is Professor Barber's, which holds that dual federalism is necessarily incoherent because public goods like liberty and democracy must be defined by national actors in a national forum, leaving no room for more particularistic arguments from "states" rights." The second is more in the vein of conventional wisdom, which believes dual federalism became extinct because it was not susceptible to principled application over time.

\section{Professor Barber's Argument}

The central claim of Professor Barber's essay is that dual federalism-by which, as I have said, he seems to mean dual sovereigntyis logically self-defeating. "Should there be a dual federalist as well as a national reading of . . . any . . . matter material to the federalism debate, including the nature of the Constitution as a whole-if there is an interpretive choice of any description, dual federalism will (or should) lose the debate." 156 This proposition extends not only to "the Supremacy Clause," but also to "the Tenth Amendment, or the enumeration of powers, or the breadth of national powers, or the Framers' intentions, or the formation of the Union, 
or the nature of liberty." 157 Every aspect of our constitutional law, in other words, is to be construed in a nationalist way.

In assessing the scope of this proposition, much would seem to depend on how often we think "there is an interpretive choice of any description." On some issues there may not be. John Marshall wrote in Gibbons, for example, that "[t]he enumeration [of federal powers] presupposes something not enumerated," 158 which seems to mean that the very notion that the national government must operate within finite bounds is not really open to question. But that is arguably enough to decide a case like United States $v$. Lopez; ${ }^{159}$ the critical moment in that case occurred when Justice O'Connor asked Solicitor General Drew Days whether, if the Gun Free School Zones Act were constitutional, he could think of anything Congress might do that would be outside its power. ${ }^{160}$ He could not, and that was that; the Court was simply unwilling to transgress Marshall's principle that something must lie outside Congress's enumerated powers. ${ }^{161}$ Although some very smart justices dissented in Lopez, I would be tempted to classify it as a case in which there was not "an interpretive choice of any description."

I doubt, however, that Professor Barber would agree. Barber sums up his argument this way:

The states' rights debate is a national debate, conducted in a national forum. An admittedly local good can't count as a reason in that forum. The dual federalist who submits to the forum loses the debate before it begins because the good that would justify dual federalism would be a nationally recognized good applied by a national agency as a restraint on the states. ${ }^{162}$

It's hard to know what to make of this argument. As an empirical description of the actual debates that take place in national forums, it's simply incorrect. Consider, for example, a typical appropriations debate in Congress. A congressman may well argue for a benefit to his local district-say, a "bridge to nowhere" or a research grant to a local university. To say that people cannot make arguments based on local goods in a national forum is to ignore what goes on in the halls of national government every day. Professor Barber's claim would also render incomprehensible Wechsler's influential argument that the primary protection for state autonomy and prerogatives comes from the states' ability to argue for 
those things in a national forum-the Congress-through their elected representatives. ${ }^{163}$ If a national forum can consider only "national goods"-whatever those are-then how are the "political safeguards of federalism" to operate?

Professor Barber's argument is also flatly inconsistent with the role of national courts in enforcing the boundaries of state and national authority in federal systems. Commentators often emphasize that arguments for limiting national power vis-à-vis the subnational units can and should be presented in a national forum-a proposition that Barber argues is simply impossible. The European jurist Koen Lenaerts, for instance, has stated that "[f] ederalism is present whenever a divided sovereign is guaranteed by a national or supranational constitution and umpired by the supreme court of the common legal order."164 And, in fact, the constitutional courts of many federal systems hear, with some regularity, the sorts of claims that national power must be limited. ${ }^{165}$ Alphonso Lopez's (victorious) lawyer would no doubt be surprised to hear that it is impossible to make arguments for limiting national power vis-à-vis the states in a national forum like the Supreme Court.

But perhaps Professor Barber means this to be a normative argument: the only reasons that should count in a national forum are national reasons. It's not clear why this should be true; the argument that states' rights claims must fail because only national reasons should count seems to assume the very point in issue. But even if we grant the premise, it is hardly clear that Barber's conclusion follows. On his view, the appropriation-seeking congressman must explain why a federal expenditure in his district benefits the nation as a whole. But can he not point out that few federal programs benefit all Americans at once, or evenly, and that by benefiting some (his constituents) we benefit the larger whole? ${ }^{166}$ That is certainly the premise behind federal disaster relief funds, for example. The broader point is that it may not always be easy to distinguish between national and local goods.

The critical case of this ambiguity is the value of state sovereignty in checking national power. As Madison suggested in The Federalist No. 51, federalism is a central ingredient in our system of checks and balances, part of the "double security" for individual liberty at the heart of the Constitution. ${ }^{167}$ If that is right, then why 
isn't state sovereignty itself a national good? If it is, then it seems to me that Professor Barber's argument collapses in on itself. ${ }^{168}$

Professor Barber seems to deny that checks and balances can itself be a national good when he says that "Marshall's was a positive constitutionalism; dual federalism belongs to a tradition of negative constitutionalism. Marshall's positive constitutionalism makes more sense than negative constitutionalism because establishing a government to pursue good things makes sense while establishing a government mainly to prevent government from doing bad things makes no sense." 169 This is a highly contestable assertion, of course. ${ }^{170}$ Much of constitutional law is concerned with preventing government from doing bad things. ${ }^{171}$ The original Constitution was obsessed with dividing and checking governmental power, ${ }^{172}$ and Barber's dismissal of "negative constitutionalism" (it "makes no sense") condemns not only federalism but also separation of powers and individual rights. It would condemn Marshall's own jurisprudence, which struck down governmental action when it transgressed constitutional limitations. ${ }^{173}$ Moreover, limiting the power of the national government is not simply a "negative" enterprise. Much of the point is to preserve the autonomy of state governments to pursue their own "positive" programs-for example, permitting gay marriage and medicinal marijuana, or protecting the environment more rigorously than federal law-without national interference. ${ }^{174}$

In any event, Professor Barber's claim that proponents of state sovereignty simply can't argue for that value in a national forum like Congress or the Supreme Court ${ }^{175}$ reminds me of Mark Twain's reply when asked if he believed in infant baptism: "Of course I do," he said. "I've seen it done." People who believe in state sovereignty do make these arguments in national forums, and they are unlikely to stop simply because someone tells them that it's impossible. It is far better, in my view, to engage the arguments that people actually do make on their merits.

\section{Determinate Line Drawing and the Frankfurter Constraint}

All that said, I agree with Professor Barber that dual federalismdefined considerably more narrowly than he suggests-is a failed 
approach; I simply disagree about the reason for that failure. Our disagreement has practical consequences. For one thing, our contrasting accounts of the reason dual federalism must fail point in different directions for the use of dual federalist doctrines to limit state authority. If the problem with dual federalism is that we need a single nationalist vision of liberty and democracy, then we have every reason to defend exclusive zones of national authority, like foreign affairs or immigration, from intrusions by the states. ${ }^{176}$ But if, as I argue in this section, the real trouble is that exclusive spheres of authority simply cannot be defined and maintained in a principled way, then that difficulty will plague dual federalism whether it is used to restrict state or national power.

Dual federalism was primarily a model of judicial review, and as such it had to be amenable to the institutional constraints faced by courts. As I have argued at greater length elsewhere, ${ }^{177}$ the primary constraint on courts is that they must make decisions according to law; to invoke Hamilton again, they must exercise "judgment," not "will." 178 Or, as Wechsler put it, judicial decision making must be "principled" in a way that legislative decision making need not be. ${ }^{179}$ Most assessments of dual federalism have agreed that dual federalism failed because, especially as the national economy became more integrated and the public came to expect more from government, the separate spheres model became incapable of principled application. As Vicki Jackson has observed, "[W]ithout written guideposts on the content of the enclaves in the face of changing economies and functions of government, the substantive enclave theory is unworkable." 180

In the 1930s, Felix Frankfurter published an analysis of the Supreme Court's nineteenth-century decisions construing the boundaries of dual federalism under the Commerce Clause that emphasized the Court's need and desire to avoid the appearance of "judicial policy-making." ${ }^{181}$ Larry Lessig calls this the "Frankfurter Constraint," and he contends that it is fundamental to judicial legitimacy. ${ }^{182}$ "[A] rule is an inferior rule," he writes, "if, in its application, it appears to be political, in the sense of appearing to allow extra-legal factors to control its application." ${ }^{183}$ And when the Court perceives that it is incurring costs to its legitimacy by pursuing a doctrinal rule perceived to be political, we can expect the Court to abandon that rule and try something else. ${ }^{184}$ 
So it was with dual federalism. A doctrinal model that calls upon the Court to define and police separate and exclusive spheres of state and national authority puts enormous pressure on the Court's ability to draw the boundary line in a principled and consistent way. ${ }^{185}$ After a century and a half of trying to draw lines between commercial and police powers regulation, ${ }^{186}$ essentially national and essentially local regulation, ${ }^{187}$ manufacturing and commerce, ${ }^{188}$ items in the "stream of commerce" and those without, ${ }^{189}$ and "direct" and "indirect" effects on interstate commerce, ${ }^{190}$ the Court found itself under fire for its inability to seem principled in that effort. ${ }^{191}$ Perhaps these doctrinal distinctions collapsed under their own weight, causing the Court to change course. ${ }^{192}$ Perhaps the perceived inconsistency of the Court's results helped mobilize popular support for President Roosevelt's "court-packing" plan, and the threat of that plan in turn caused the Court's "switch in time." 193 Either way, the point is that the essential indeterminacy of the line between state and national spheres was a key factor in dual federalism's demise.

If this is right, then at least as a historical matter, dual federalism did not die because there is anything fundamentally incoherent about the notion of state sovereignty or differing state conceptions of democracy or liberty. There is, then, no necessary impediment to alternative models of dual sovereignty that do not raise the same line-drawing problems. ${ }^{194}$ Moreover, if indeterminacy is the root problem with dual federalism, then that problem will afflict any dual federalist model, including one that restricts state power as much as one that restricts national power. The persistent nostalgia for exclusive zones of national power over areas like foreign affairs or immigration, then, remains puzzling.

\section{Conclusion}

Justice O'Connor said in New York v. United States that "discerning the proper division of authority between the Federal Government and the States" is "our oldest question of constitutional law." ${ }^{195}$ But the persistence of that question should not blind us to the ways in which the federalism debate has changed over the course of our history. Although the dual federalist model dominated that debate for the first century and a half, it collapsed in 1937 and has 
found few adherents since. Dual sovereignty remains, and a variety of other models for preserving the constitutional equilibrium between the nation and the states have arisen to take dual federalism's place. But outside of a few pockets wherein the courts seek to maintain exclusive zones of national control over foreign affairs, immigration, and the like, dual federalism has given way to cooperative federalism, subsidiarity, process federalism, and sovereign immunity.

I fear, however, that the puzzling persistence of dual federalism as an analytical category, particularly among critics of the Supreme Court's efforts to enforce constitutional constraints on national power, has distorted federalism's research agenda. We spend too much time discussing the follies of exclusive subject matter categories as a tool for dividing state and federal regulatory jurisdiction, and far too little analyzing the models of federalism that are actually in play. Any number of more fruitful projects call out for study: we are beginning to have some helpful analyses and case studies of the impact of political parties on the political safeguards of federalism, for example, but much more remains to be done. Heather Gerken and Jessica Bulman-Pozen's theoretical account of "uncooperative federalism" called for careful analyses of the way that state and national administrators actually interact in practice, but relatively few have answered the call. And little has been done to bridge the gap between scholars of public administration steeped in the practical intricacies of fiscal federalism and legal scholars analyzing how to interpret the Spending Clause.

Vestiges of dual federalism should be rooted out, and the Court should be warned against tendencies toward relapse. But for the most part, the horse of dual federalism is dead, and we should quit beating it. The more fundamental debate about dual sovereignty, however, remains worth having.

\section{NOTES}

I initially contributed this essay to the American Society for Political and Legal Philosophy's Annual Meeting, panel on "Federalism and Subsidiarity: Against Dual Federalism," which convened in August 2011, and I have revised it only slightly in light of the Supreme Court's health care 
and immigration decisions in June 2012. I am grateful to Jim Fleming and Jacob Levy for inviting me to participate and to Sotirios Barber, whose paper "Defending Dual Federalism: A Self-Defeating Act" provides the focus for these comments.

1. Edward S. Corwin, "The Passing of Dual Federalism," Virginia Law Review 36 (1950): 1-22.

2. United States v. Lopez, 514 U.S. 549 (1995) (striking down the federal Gun Free School Zones Act - the first time the Court had struck down an act of Congress as outside the commerce power since the 1930s).

3. Printz v. United States, 521 U.S. 898 (1997) (striking down provisions of the Brady Act on the ground that they required state executive officials to implement federal law).

4. See Ernest A. Young, "Dual Federalism, Concurrent Jurisdiction, and the Foreign Affairs Exception," George Washington Law Review 69 (2001): 139-88.

5. See, e.g., Gonzales v. Raich, 545 U.S. 1 (2005) (upholding, by a vote of 6 to 3, application of the national Controlled Substances Act to the medicinal use of homegrown marijuana).

6. Wickard v. Filburm, 317 U.S. 111 (1942).

7. See Young, "Dual Federalism, Concurrent Jurisdiction, and the Foreign Affairs Exception," 146-50 (collecting examples of this approach).

8. Compare Sotirios A. Barber, "Defending Dual Federalism: A SelfDefeating Act," in this volume, with Malcolm M. Feeley and Edward Rubin, Federalism: Political Identity and Tragic Compromise (Ann Arbor: University of Michigan Press, 2008).

9. Jenna Bednar and William N. Eskridge Jr., "Steadying the Court's 'Unsteady Path': A Theory of Judicial Enforcement of Federalism," Southern Califormia Law Review 68 (1995): 1447, 1448.

10. Alpheus Thomas Mason, "The Role of the Court," in Federalism: Infinite Variety in Theory and Practice, ed. Valerie A. Earle (Itasca, IL: F. E. Peacock, 1968), 8, 24-25; see also Anthony J. Bellia Jr., Federalism (New York: Aspen, 2010), 183 ("The dual federalism paradigm understands federal and state governments to operate in different spheres of authority.").

11. Corwin, "The Passing of Dual Federalism," 4.

12. See, e.g., John Kincaid, "From Dual to Coercive Federalism in American Intergovernmental Relations," in Globalization and Decentralization: Institutional Contexts, Policy Issues, and Intergovernmental Relations in Japan and the United States, ed. Jong S. Jun and Deil S. Wright (Washington, DC: Georgetown University Press, 1996), 29 ("Dual federalism was marked ... [by] maintenance of the independent integrity of federal powers and state powers through separations of national and state spheres of action."). 
13. See generally U.S. Term Limits, Inc. v. Thornton, 514 U.S. 779,838 (1995) (Kennedy, J., concurring) ("Federalism was our Nation's own discovery. The Framers split the atom of sovereignty."); Gordon S. Wood, The Creation of the American Republic 1776-1787 (Chapel Hill: University of North Carolina Press, 1969), 524-32; Akhil Reed Amar, "Of Sovereignty and Federalism," Yale Law Joumal 96 (1987): 1425, 1434-36.

14. Seminole Tribe of Fla. v. Florida, 517 U.S. 44, 151-52 (1996) (Souter, $\mathrm{J}$, dissenting).

15. McCulloch v. Maryland, 17 U.S. (4 Wheat.) 316, 410 (1819).

16. Robert M. Cover and T. Alexander Aleinikoff, "Dialectical Federalism: Habeas Corpus and the Court," Yale Law Joumal 86 (1977): 1035, 1047-48.

17. See, e.g., Sir William Blackstone, Commentaries on the Laws of England (Oxford: Clarendon Press, 1765-1769), *49 ("[T] here is and must be in all [governments] a supreme, irresistible, absolute, uncontrolled authority, in which the jura summi imperii, or the rights of sovereignty, reside."); Jean Bodin, Six Books of the Commonwealth, abr. and trans. M. Tooley (Oxford: B. Blackwell, 1955 [1576]), bk. 2, ch. I, 52-53; Thomas Hobbes, Leviathan, ed. N. Fuller (Chicago: Britannica, 1952 [1651]), pt. II, ch. 29, 150-51.

18. See Wood, The Creation of the American Republic, 526-30 (describing how the Federalists initially eschewed use of the term "sovereignty" and adopted it only after it became apparent that too many of their countrymen were wedded to it); Samuel Beer, To Make a Nation: The Rediscovery of American Federalism (Cambridge, MA: Belknap Press, 1993), 150-51 (observing that the American view of sovereignty was "radically different" from that of British tradition).

19. See, e.g., Abram Chayes and Antonia Handler Chayes, The New Sovereignty: Compliance with International Regulatory Agreements (Cambridge, MA: Harvard University Press, 1998).

20. See Edward L. Rubin and Malcolm Feeley, "Federalism: Some Notes on a National Neurosis," UCLA Law Review 41 (1994): 903, 910-14.

21. See, e.g., Sanford Levinson, Our Undemocratic Constitution: Where the Constitution Goes Wrong (And How We the People Can Correct It) (New York: Oxford University Press, 2006), 167 (decrying " $[\mathbf{t}]$ he functional impossibility of amending the [U.S.] Constitution with regard to anything truly significant"); see also Joseph Raz, "On the Authority and Interpretation of Constitutions: Some Preliminaries," in Constitutionalism: Philosophical Foundations, ed. Larry Alexander (New York: Cambridge University Press, 1998), 152-53 (identifying entrenchment as a basic function of constitutions).

22. Jenna Bednar, The Robust Federation: Principles of Design (Cambridge: Cambridge University Press, 2009), 18-19.

23. See ibid. 
24. New York v. United States, 505 U.S. 144, 162 (1992) (quoting Texas v. White, 74 U.S. (7 Wall.) 700, 725 (1869)); see also Tafflin v. Levitt, 493 U.S. 455,458 (1990) ("Under our federal system, the States possess sovereignty concurrent with that of the Federal Government.").

25. See Ernest A. Young, "The Constitution Outside the Constitution," Yale Law Journal 117 (2007): 408.

26. Cf. Egelhoff v. Egelhoff, 532 U.S. 141, 160-61 (2001) (Breyer, J., dissenting) (suggesting that "in today's world, filled with legal complexity, the true test of federalist principle may lie, not in the occasional constitutional effort to trim Congress's commerce power at its edges . . but rather in those many statutory cases where courts interpret the mass of technical detail that is the ordinary diet of the law"); Ernest A. Young, " "The Ordinary Diet of the Law': The Presumption against Preemption in the Roberts Court," Supreme Court Review (2011): 253 (arguing that the preemptive effect of federal statutes is the most important issue in federalism doctrine).

27. Barber, "Defending Dual Federalism."

28. See Ernest A. Young, "The Rehnquist Court's Two Federalisms," Texas Law Review 83 (2004): 1.

29. Barber, "Defending Dual Federalism."

30. See also Larry Kramer, "Understanding Federalism," Vanderbilt Law Review 47 (1994): 1485, 1499 ("[J] ust because it's no longer possible to maintain a fixed domain of exclusive state jurisdiction it's not necessarily impossible to maintain a fluid one.").

31. Barber, "Defending Dual Federalism."

32. See, e.g., Gregory v. Ashcroft, 501 U.S. 452, 457 (1991) ("As every schoolchild learns, our Constitution establishes a system of dual sovereignty between the States and the Federal Government. This Court also has recognized this fundamental principle."); see also Ernest A. Young, "Making Federalism Doctrine: Fidelity, Institutional Competence, and Compensating Adjustments," William and Mary Law Review 46 (2005): 1733 (collecting textual and historical arguments).

33. See, e.g., United States v. Morrison, 529 U.S. 598, 618 n. 8 (2000) ("With its careful enumeration of federal powers and explicit statement that all powers not granted to the Federal Government are reserved, the Constitution cannot realistically be interpreted as granting the Federal Government an unlimited license to regulate."); Jack N. Rakove, Original Meanings: Politics and Ideas in the Making of the Constitution (London: Vintage, 1996), 162 (discussing the inevitability of state sovereignty at the Founding).

34. Barber, "Defending Dual Federalism" (quoting The Federalist No. $45)$. 
35. See ibid.

36. Alternatively, one might think of Professor Barber's argument as simply collapsing the Constitution's specific provisions into one phrase of the Preamble ("promote the general welfare"). See Harvey Mansfield, "The Formal Constitution: A Comment on Sotirios A. Barber," American Journal of Jurisprudence 42 (1997): 187.

37. 505 U.S. 144, 157 (1992).

38. See, e.g., Young, "Making Federalism Doctrine," 1754-65 (discussing the obligation of constitutional fidelity).

39. Barber, "Defending Dual Federalism." Strictly speaking, this formulation is tautological because, under the Tenth Amendment, the states' reserved powers begin where the national authority ends. See U.S. Const., amend. X ("The powers not delegated to the United States by the Constitution, nor prohibited by it to the states, are reserved to the states respectively, or to the people.").

40. See, e.g., Barber, "Defending Dual Federalism" ("[A] true love of democracy would move people to construe the Fourteenth and Fifteenth Amendments in a manner that permitted Congress and the Supreme Court to police the states' performance and devolve or resume responsibility as circumstances required.").

41. See, e.g., Prigg v. Pennsylvania, 41 U.S. 539 (1842) (holding that the national Fugitive Slave Law preempted state efforts to provide due process for persons accused of being escaped slaves); H. W. Brands, American Colossus: The Triumph of Capitalism 1865-1900 (New York: Doubleday, 2010), 53 (recounting how Congress enacted laws providing for federal enforcement of exploitative "coolie" labor contracts between railroad companies and Chinese immigrants); Ann Althouse, "The Vigor of Anti-commandeering Doctrine in Times of Terror," Brooklyn Law Review 69 (2004): 1231, 125357 (describing opposition by state and local governments to provisions of the USA PATRIOT Act).

42. The Federalist No. 28, at 138-39 (Alexander Hamilton), ed. George W. Carey and James McClellan (Indianapolis, IN: Liberty Fund, 2001).

43. Rubin and Feeley, "Federalism: Some Notes on a National Neurosis," 910-11.

44. Ibid., 912.

45. Barber, "Defending Dual Federalism."

46. Kenneth A. Shepsle, "Congress Is a 'They,' Not an 'It': Legislative Intent as an Oxymoron," International Review of Law and Economics 12 (1992): 239.

47. Barber, "Defending Dual Federalism."

48. Ibid. 
49. Lochner v. New York, 198 U.S. 45, 75-76 (1905) (Holmes, J., dissenting).

50. 17 U.S. (4 Wheat.) 316, 423 (1819). See also Marbury v. Madison, 5 U.S. (1 Cranch) 137, 176 (1803) ("The powers of the legislature are defined, and limited; and that those limits may not be mistaken, or forgotten, the constitution is written.").

51. Gibbons v. Ogden, 22 U.S. (9 Wheat.) 1, 195 (1824). This formulation arguably combines dual federalism with a distinct model of "collective action" federalism, which I discuss later. The important point is simply that Gibbons plainly rejects plenary congressional power to delegate and recall power to and from the states.

52. Morton Grodzins, "The American Federal System," in A Nation of States: Essays on the American Federal System, ed. Robert A. Goldwin (Chicago: Rand McNally, 1961), 1-2.

53. Philip J. Weiser, "Towards a Constitutional Architecture for Cooperative Federalism," North Carolina Law Review 79 (2001): 663, 665.

54. See also Martin H. Redish, The Constitution as Political Structure (New York: Oxford University Press, 1995), 26 (contrasting "dual" and "cooperative" federalism).

55. Joseph F. Zimmerman, Contemporary American Federalism: The Growth of National Power (Westport, CT: Praeger, 1992). For a quite different critique of cooperative federalism, see Michael S. Greve, The Upside-Down Constitution (Cambridge, MA: Harvard University Press, 2012), 184-86 (arguing that cooperative federalism is designed to facilitate cartels among the states that subvert the original competitive structure of federalism).

56. Kramer, "Understanding Federalism," 1544.

57. Ibid.

58. Jessica Bulman-Pozen and Heather K. Gerken, "Uncooperative Federalism," Yale Law Journal 118 (2009): 1256, 1258-59.

59. Ibid, 1259.

60. Grodzins, "The American Federal System," 22.

61. See New York v. United States, 505 U.S. 144 (1992); Printz v. United States, 521 U.S. 898 (1997); but see Testa v. Katt, 330 U.S. 386 (1947) (holding that Congress may generally require state courts to entertain claims under federal law).

62. See South Dakota v. Dole, 483 U.S. 203 (1987).

63. Donald H. Regan, "How to Think about the Federal Commerce Power and Incidentally Rewrite United States v. Lopez," Michigan Law Review 94 (1995): 554, 557; see also Ann Althouse, "Enforcing Federalism after United States v. Lopez," Arizona Law Review 38 (1996): 793, 817 (arguing for a "jurisprudence that looks deeply into why it is good for some matters to 
be governed by a uniform federal standard, why it is good for some things to remain under the control of various states, and what effect these choices will have on the federal courts"); Stephen Gardbaum, "Rethinking Constitutional Federalism," Texas Law Review 74 (1996): 795, 826-27 (making a similar suggestion).

64. EC Treaty art. 5 (ex art. $3 b$ ).

65. See, e.g., Edward T. Swaine, "Subsidiarity and Self-Interest: Federalism at the European Court of Justice," Harvard International Law Journal 41 (2000): 1, 5 ("Subsidiarity is a critical reaction not only to the gradual shift in legislative authority from the Member States-dominated Council to more autonomous Community institutions, but also to the Court of Justice's expansive interpretation of Community powers against the apparent interest of Member States."). For a compelling argument that subsidiarity is not, in fact, a suitable or effective protection for Member State autonomy, see Gareth Davies, "Subsidiarity: The Wrong Idea, in the Wrong Place at the Wrong Time," Common Market Law Review 43 (2006): 63.

66. Robert D. Cooter and Neil Siegel, "Collective Action Federalism: A General Theory of Article I, Section 8," Stanford Law Review 63 (2010): 115.

67. Ibid, 119.

68. See The Federalist No. 78, at 405 (Alexander Hamilton). Notably, Professors Cooter and Siegel remain mostly agnostic as to whether their approach is suitable for judicial enforcement. See Cooter and Siegel, "Collective Action Federalism," 154.

69. See, e.g., George A. Bermann, "Taking Subsidiarity Seriously: Federalism in the European Community and the United States," Columbia Law Review 94 (1994): 331, 391 ("The same characteristics that make the inquiry difficult for the political branches to conduct-namely, uncertainty about how much localism really matters on a given issue, the heavy reliance on prediction and the probabilities of competing scenarios, the possibility of discretionary tradeoffs between subsidiarity and proportionality, and the sheer exercise of political judgment entailed-make the inquiry even more problematic for the Court."); Ernest A. Young, "Protecting Member State Autonomy in the European Union: Some Cautionary Tales from American Federalism," New York University Law Review 77 (2002): 1612, 1677-82 (describing early efforts by the European Court of Justice to enforce subsidiarity).

70. See, e.g., Young, "Making Federalism Doctrine," 1846-47; Young, "Protecting Member State Autonomy in the European Union," 1679-81.

71. Grodzins, "The American Federal System," 17.

72. Professor Siegel's more recent work suggests that he believes that courts should be quite deferential to Congress in evaluating collective action arguments for national action. See Neil S. Siegel, "Free Riding 
on Benevolence: Collective Action Federalism and the Minimum Coverage Provision," Law and Contemporary Problems 75 (2012): 29, 33 ("[T]he decisive commerce power question is whether Congress could reasonably conclude that a requirement to obtain health insurance coverage or pay a fee will help to solve one or more significant collective action problems involving multiple states."); see also ibid, 32 n. 25 ("Heightened scrutiny in Commerce Clause cases is unheard of in the Court's contemporary federalism jurisprudence."). In that case, collective action federalism would serve largely to erase the minimal doctrinal checks on national action that currently exist. On the other hand, any serious and rigorous effort by courts to review whether particular federal statutes responded to actual collective action problems that the states cannot resolve on their own might well end up striking down far more federal statutes than current doctrine.

73. See, e.g., Neil S. Siegel, "Distinguishing the 'Truly National' from the 'Truly Local': Customary Allocation, Commercial Activity, and Collective Action," Duke Law Journal 62 (2012): 797 (arguing that collective action is a superior model to approaches relying on a customary allocation of federal and state functions).

74. 469 U.S. 528 (1985).

75. William W. Van Alstyne, "The Second Death of Federalism," Michigan Law Review 83 (1985): 1709. The first death, of course, occurred in the New Deal revolution.

76. 469 U.S. at 554 (quoting EEOC v. Wyoming, 450 U.S. 226, 236 (1983)).

77. But see Andrzej Rapaczynski, "From Sovereignty to Process: The Jurisprudence of Federalism after Garcia," Supreme Court Review (1985): 341 (anticipating that meaningful process-based protections for states would develop out of Garcia).

78. John Hart Ely, Democracy and Distrust: $A$ Theory of Judicial Review (Cambridge, MA: Harvard University Press, 1980).

79. See generally Ernest A. Young, "Two Cheers for Process Federalism," Villanova Law Review 46 (2001): 1349.

80. See Ely, Democracy and Distrust, 73-104.

81. Herbert Wechsler, "The Political Safeguards of Federalism: The Role of the States in the Composition and Selection of the National Government," Columbia Law Review 54 (1954): 543. For Madison's earlier version, see The Federalist Nos. 45 and 46, at 237-48.

82. See, e.g., Larry D. Kramer, "Putting the Politics Back into the Political Safeguards of Federalism," Columbia Law Review 100 (2000): 215 (stressing parties); Franita Tolson, "Partisan Gerrymandering as a Safeguard of Federalism," Utah Law Review (2010): 859 (stressing redistricting). 
83. Bradford R. Clark, "Separation of Powers as a Safeguard of Federalism," Texas Law Review 79 (2001): 1321, 1339-40.

84. Gregory v. Ashcroft, 501 U.S. 452, 460-61 (1991).

85. Will v. Mich. Dept. of State Police, 491 U.S. 58, 65 (1989).

86. Atascadero St. Hosp. v. Scanlon, 473 U.S. 234, 242 (1985).

87. Pennhurst St. Sch. and Hosp. v. Halderman, 451 U.S. 1, 16-18 (1980).

88. Rice v. Santa Fe Elevator Comp., 331 U.S. 218, 230 (1947).

89. See William N. Eskridge Jr. and Philip P. Frickey, "Quasi-constitutional Law: Clear Statement Rules as Constitutional Lawmaking," Vanderbilt Law Review 45 (1992): 593 (surveying arguments pro and con).

90. See Ernest A. Young, "The Continuity of Statutory and Constitutional Interpretation: An Essay for Phil Frickey," Califomia Law Review 98 (2010): 1371.

91. See note 61 and accompanying text.

92. See Young, "Two Cheers for Process Federalism," 1349, 1360-61.

93. See ibid.; see also Greve, The Upside-Down Constitution, 351-53 (arguing that the anticommandeering increases the accountability of government officials).

94. Barber, "Defending Dual Federalism."

95. See Ernest A. Young, "State Sovereign Immunity and the Future of Federalism," Supreme Court Review (1999): 1.

96. 426 U.S. 833 (1976).

97. 134 U.S. 1 (1890).

98. The Eleventh Amendment provides that "[t]he Judicial power of the United States shall not be construed to extend to any suit in law or equity, commenced or prosecuted against one of the United States by Citizens of another State, or by Citizens or Subjects of any Foreign State." But the Court has made clear that "sovereign immunity derives not from the Eleventh Amendment but from the structure of the original Constitution itself." Alden v. Maine, 527 U.S. 706, 728 (1999).

99. 517 U.S. 44 (1996).

100. Alden v. Maine, 527 U.S. 706 (1999) (state courts); Federal Maritime Comm'n v. South Carolina Ports Authority, 535 U.S. 743 (2002) (administrative agencies).

101. See, e.g., College Savings Bank v. Florida Prepaid Postsecondary Education Expense Board, 527 U.S. 666 (1999); Kimel v. Florida Board of Regents, 528 U.S. 62 (2000); Board of Trustees of University of Alabama v. Garrett, 531 U.S. $356(2001)$.

102. See generally Young, "The Rehnquist Court's Two Federalisms," 154-60.

103. See, e.g., Brown v. Allen, 344 U.S. 443 (1953).

104. See, e.g., Stone v. Powell, 428 U.S. 465 (1976) (holding that chal- 
lenges to state convictions under the Fourth Amendment "exclusionary rule" are not reviewable in habeas); Wainwright v. Sykes, 433 U.S. 72 (1977) (tightening the doctrine of "procedural default" that bars federal habeas review where the petitioner failed to comply with state procedural rules); Teague v. Lane, 489 U.S. 288 (1988) (holding that habeas petitioners may not avail themselves of "new rules" of constitutional law announced after their convictions have become final).

105. 110 Stat. 1214; see also Richard H. Fallon Jr., John F. Manning, Daniel J. Meltzer, and David L. Shapiro, Hart and Wechsler's The Federal Courts and the Federal System (Eagan, MN: Foundation Press, 6th ed. 2009), $1157-58$.

106. Under the "general common law," the federal courts applied judge-made rules of decision rather than state law to private litigation between parties from different states. See, e.g., Swift v. Tyson, 41 U.S. (16 Pet.) 1 (1842). Although these cases did not initially have the effect of excluding state regulatory authority-at the outset, they simply reflected the decision of states to adopt uniform rules on subjects like commercial paper-they later came to have that effect. See generally Tony Freyer, Harmony and Dissonance: The Swift and Erie Cases in American Federalism (New York: NYU Press, 1981); William Fletcher, "The General Common Law and Section 34 of the Judiciary Act of 1789: The Example of Marine Insurance," Harvard Law Review 97 (1984): 1513.

107. United States v. E. C. Knight Co., 156 U.S. 1 (1895).

108. Hammer v. Dagenhart, 247 U.S. 251 (1918).

109. See, e.g., Barry Cushman, Rethinking the New Deal Court: The Structure of a Constitutional Revolution (New York: Oxford University Press, 1998).

110. 301 U.S. 1 (1937).

111. 317 U.S. 111 (1942).

112. Corwin, "The Passing of Dual Federalism," 17.

113. See also, e.g., Robert A. Schapiro, Polyphonic Federalism: Toward the Protection of Fundamental Rights (Chicago: University of Chicago Press, 2009), 55 (characterizing the Court's current jurisprudence as reflecting a dual federalist model).

114. Barber, "Defending Dual Federalism."

115. 514 U.S. 779 (1995).

116. Barber, "Defending Dual Federalism." Of course, none of the Court's cases have actually involved secession or nullification, and the Court has repeatedly affirmed the supremacy of federal law. See, e.g., Gregory v. Ashcroft, 501 U.S. 452, 460 (1991) ("The Federal Government holds a decided advantage in this delicate balance: the Supremacy Clause. . . . As long as it is acting within the powers granted it under the Constitution, Congress may impose its will on the States."). 
117. See Term Limits, 857-62 (Thomas, J., dissenting); see also ibid. at 852-53 "The question raised by the present case . . is not whether any principle of state sovereignty implicit in the Tenth Amendment bars congressional action that Article I appears to authorize, but rather whether Article I bars state action that it does not appear to forbid.").

118. See, e.g., PLIVA, Inc. v. Mensing, 131 S. Ct. 2567 (2011) (plurality opinion); see also Young, "'The Ordinary Diet of the Law,' " 326-29 (discussing Justice Thomas's preemption jurisprudence).

119. 514 U.S. 549 (1995).

120. 529 U.S. $598(2000)$.

121. See Young, "Dual Federalism, Concurrent Jurisdiction, and the Foreign Affairs Exception,” 157-63.

122. 317 U.S. 111 (1942).

123. 514 U.S. 549, 556-59, 560 (1995); see also Nat'l Fed'n of Indep. Bus. v. Sebelius, 132 S. Ct. 2566, 2643 (2012) (Scalia, Kennedy, Thomas, and Alito, JJ., dissenting) (stating that Wickard is the "ne plus ultra of expansive Commerce Clause jurisprudence" but accepting it as valid).

124. See Lopez, 514 U.S. at 559 ("[W]e have upheld a wide variety of congressional Acts regulating intrastate economic activity where we have concluded that the activity substantially affected interstate commerce."); ibid., 561 (noting that the Gun Free School Zones Act was "a criminal statute that by its terms has nothing to do with 'commerce' or any sort of economic enterprise, however broadly one might define those terms").

125. 22 U.S. (9 Wheat.) at 195. Under Lopez and Morrison, an activity need merely be "economic" in nature to fall within Congress's power. See, e.g., Lopez, 514 U.S. at 559; Morrison, 529 U.S. at 613 (noting that "our cases have upheld Commerce Clause regulation of intrastate activity" so long as "that activity is economic in nature"),

126. 545 U.S. 1 (2005).

127. See ibid., 29 (insisting that "state action cannot circumscribe Congress's plenary commerce power").

128. See ibid., 35-42 (Scalia, J., concurring in the judgment).

129. 132 S. Ct. 2566 (2012).

130. Ibid., 2593-2600. Justices Ginsburg, Breyer, Sotomayor, and Kagan joined this portion of the Chief Justice's opinion.

131. See ibid., 2585-91 (opinion of Roberts, C.J.); ibid., 2647-48 (joint opinion of Scalia, Kennedy, Thomas, and Alito, JJ.). The Chief Justice explained that this portion of his opinion was not dictum because the unconstitutionality of the mandate under the Commerce Clause triggered a presumption in favor of "saving" the act by construing it as a tax. See ibid., 2600-01 (opinion of Roberts, C.J.); see generally Adrian Vermeule, "Saving Constructions," Georgetown Law Joumal 85 (1997): 1945. 
132. See 132 S. Ct. at 2587 ("The individual mandate, however, does not regulate existing commercial activity. It instead compels individuals to become active in commerce by purchasing a product, on the ground that their failure to do so affects interstate commerce. Construing the Commerce Clause to permit Congress to regulate individuals precisely because they are doing nothing would open a new and potentially vast domain to congressional authority.").

133. The more important federalism holding in NFIB was the Court's conclusion-joined by a whopping seven justices - that the PPACA's expansion of Medicaid exceeded the limits of Congress's power under the Spending Clause. See $132 \mathrm{~S}$. Ct. at 2601-07. But again, spending is an instrument of federal regulation, not a subject matter field, and the Court's limit did not rest on any suggestion that the Medicaid expansion entered an exclusive state sphere.

134. Barber, "Defending Dual Federalism."

135. See, e.g., Young, "The Rehnquist Court's Two Federalisms," 154-60.

136. See Young, "Dual Federalism, Concurrent Jurisdiction, and the Foreign Affairs Exception," 154.

137. See, e.g., Daniel J. Meltzer, "Overcoming Immunity: The Case of Federal Regulation of Intellectual Property," Stanford Law Review 42 (2001): 1331 (illustrating how to work around state sovereign immunity in intellectual property cases).

138. See Nevada Dept. of Human Resources v. Hibbs, 538 U.S. 721 (2003) (upholding state liability provisions of the Family Medical Leave Act as valid exercise of the Section Five power); Tennessee v. Lane, 541 U.S. 509 (2004) (holding that Congress could subject states to damages liability under the Americans with Disabilities Act for denying disabled access to courts); Central Virginia Community College v. Katz, 546 U.S. 356 (2006) (holding that Congress could abrogate the sovereign immunity of the states in certain bankruptcy cases).

139. See, e.g., Ernest A. Young, "The Story of Gregory v. Ashcroft: Clear Statement Rules and the Statutory Constitution of American Federalism," in Statutory Construction Stories, ed. William Eskridge Jr., Philip P. Frickey, and Elizabeth Garrett (Eagan, MN: Foundation Press, 2010), 196.

140. See also United States v. Comstock, 130 S. Ct. 1949 (2010) (holding that the federal civil commitment scheme for federal prisoners considered to be sexually dangerous was "necessary and proper" to Congress's power to punish violators of federal laws enacted pursuant to its enumerated powers).

141. See Lamb's Chapel v. Center Moriches Union Free Sch. Dist., 508 U.S. 384,398 (1993) (Scalia, J., concurring in the judgment). 
142. See Young, "Dual Federalism, Concurrent Jurisdiction, and the Foreign Affairs Exception," 177-85.

143. 530 U.S. $363(2000)$.

144. 539 U.S. 396 (2003).

145. United States v. Arizona, 641 F.3d 339, 352-54 (9th Gir. 2011). Although the Ninth Circuit majority also applied traditional statutory preemption principles, Judge Noonan's concurrence offered a full-throated endorsement of dual federalist exclusivity:

The foreign policy of the United States preempts the field entered by Arizona. Foreign policy is not and cannot be determined by the several states. Foreign policy is determined by the nation as the nation interacts with other nations. Whatever in any substantial degree attempts to express a policy by a single state or by several states toward other nations enters an exclusively federal field.

Ibid., 368 (Noonan, J., concurring).

146. Arizona v. United States, 132 S. Ct. 2492, 2498 (2012).

147. Ibid., 2500.

148. See ibid., 2501.

149. Roderick M. Hills Jr., "Preemption Doctrine in the Roberts Court: Constitutional Dual Federalism by Another Name?," available at http:// ssrn.com/abstract=1910761, in Business and the Roberts Court, ed. Jonathan Adler (New York: Oxford University Press, forthcoming)

150. 529 U.S. 89 (2000).

151. See Young, "Dual Federalism, Concurrent Jurisdiction, and the Foreign Affairs Exception," 178-80; see generally Young, “"The Ordinary Diet of the Law,' "332-40 (criticizing the Court's emphasis on traditional spheres of state and federal activity in preemption cases).

152. Grodzins, "The American Federal System," 3.

153. See, e.g., Julian Ku, "Gubernatorial Foreign Policy," Yale Law Joumal 115 (2006): 2380, 2414 (describing "an emerging system of gubernatorial foreign policy characterized by governors exercising independent decision-making power over matters affecting the foreign policy of the entire United States"); Ivo D. Duchacek, "Perforated Sovereignties: Towards a Typology of New Actors in International Relations," in Federalism and International Relations: The Role of Subnational Units, ed. Hans J. Michelmann and Panayotis Soldatos (New York: Oxford University Press, 1990), 1, 28 ("International activities undertaken by democratic non-central governments have already become facts of international life, however much their effects may be minimized as marginal and purely technical by some, or described as portents of diplomatic chaos by others."); Brian Hocking, "Introduction," in Foreign Relations and Federal States, ed. Brian Hocking 
(Leicester: Leicester University Press, 1993), 1, 3 ("The notion of a hierarchy of political authority, with central government acting as the effective gatekeeper between national communities and their international environment, is outdated" because of "changes in the domestic and international environments."); John Kincaid, "Constituent Diplomacy in Federal Polities and the Nation-State: Conflict and Co-operation," in Federalism and International Relations, ed. Michelmann and Soldatos, 54, 73 (arguing that international activities by subnational governments are beneficial for both economic and democratic reasons).

154. See, e.g., Jack L. Goldsmith, "Federal Courts, Foreign Affairs, and Federalism," Virginia Law Review 83 (1997): 1617, 1674 ("As international markets and means of communication have expanded, subnational units have become increasingly aware of, affected by, and in contact with foreign elements. To the extent that central governments are unable or unwilling to redress local needs and interests, state and local governments have been doing so unilaterally in both the economic and political realms.").

155. Chamber of Commerce v. Whiting, 131 S. Ct. 1968 (2011).

156. Barber, "Defending Dual Federalism."

157. Ibid.

158. Gibbons v. Ogden, 22 U.S. (9 Wheat.) 1, 195 (1824).

159. 514 U.S. 549 (1995) (striking down the national Gun Free School Zones Act as outside the reach of Congress's power under the Commerce Clause).

160. Transcript of Oral Argument in United States v. Lopez, 1994 U.S. Trans. LEXIS at **4-5 (November 8, 1994).

161. 514 U.S. at 567-68 ("To [accept the Government's argument] would require us to conclude that the Constitution's enumeration of powers does not presuppose something not enumerated . . . and that there never will be a distinction between what is truly national and what is truly local... . This we are unwilling to do.").

162. Barber, "Defending Dual Federalism."

163. Wechsler, "The Political Safeguards of Federalism," 543.

164. Koen Lenaerts, "Constitutionalism and the Many Faces of Federalism," American Joumal of Comparative Law 38 (1990): 205, 263; see also Martin Shapiro, "The European Court of Justice," in The Evolution of EU Law, ed. Paul Craig and Grainne de Burca (Oxford: Oxford University Press, 1999), 321.

165. See generally Brief of Constitutional Law Scholars as Amici Curiae in Support of Respondents, Gonzales v. Raich, No. 03-1454 (filed October 13, 2004), at 9-10 (collecting examples from Europe, Canada, and Australia).

166. See, e.g., John Donne, "Meditation XVII," in The Norton Anthology 
of English Literature, Major Authors Edition (New York: Norton, 3rd ed. 1975 [1623]), 620 ("No man is an island, entire of itself; every man is a piece of the continent, a part of the main.").

167. The Federalist No. 51, at 270 (James Madison).

168. It does no good to point out, as Barber does, that "the national government would be 'limited' in important ways even if there were no states." Barber, "Defending Dual Federalism." This is a little like saying individuals would have important rights even if they had no free speech rights. The point in each case is that the national government must be limited in the way that the Constitution provides, whether or not those protections are redundant or might be supplemented by extraconstitutional limits.

Likewise, it is no answer to say that "the dual federalist notion of limited government conflicts with other constitutional ideas," such as the principle "from The Federalist No. 45 ... that "the real welfare of the great body of the people is the supreme object to be pursued." Barber, "Defending Dual Federalism." Putting aside the quibble that The Federalist No. 45 is not the same thing as the Constitution, it is easy to demonstrate that many different constitutional ideas are in tension with one another. The Free Exercise Clause and the Establishment Clause often push in opposing directions, and individual rights like free speech often undermine constitutional principles of equality grounded in the Equal Protection Clause. See, e.g., R.A.V. v. St. Paul, 505 U.S. 377 (1992) (holding that the First Amendment protected the right to burn a cross on a black family's lawn). Certainly, the U.S. Reports are replete with cases in which the Court has thwarted the national government's ability to pursue "the real welfare of the great body of the people" in the name of some other constitutional principle. See, e.g., New York Times Co. v. United States, 403 U.S. 713 (1971) (invoking the First Amendment to reject the United States' attempt to enjoin publication of the "Pentagon Papers" on national security grounds). There is nothing for it in each of these cases but to carefully construe the scope and limits of each constitutional principle in question, with an eye toward reconciling them if possible. Neither courts nor commentators have a warrant for simply discarding a constitutional principle because it may come into conflict with some other principle they like better.

169. Barber, "Defending Dual Federalism."

170. See, e.g., Daniel J. Elazar, Exploring Federalism (Tuscaloosa: University of Alabama Press, 1987), 33 ("[F]ederalism is concerned simultaneously with the diffusion of political power in the name of liberty and its concentration on behalf of unity or energetic government.").

171. See, e.g., Youngstown Sheet and Tube Co. v. Sawyer, 343 U.S. 579, 640 (1952) (Jackson, J., concurring) ("The purpose of the Constitution was not only to grant power, but to keep it from getting out of hand."). 
172. See, e.g., The Federalist No. 51, at 267-72 (James Madison).

173. See, e.g., Fletcher v. Peck, 10 U.S. (6 Cranch) 87 (1810) (striking down a state law repealing a land grant to private parties); Dartmouth College v. Woodward, 17 U.S. (4 Wheat.) 518 (1819) (striking down a state legislature's attempt to alter the charter of a private college). It is even hard to parse the distinction between "negative" and "positive" constitutionalism, particularly in the context of federalism. John Marshall's decisions in McCulloch and Gibbons, for example, both empowered the national government to do "good things" and prevented the state governments from doing "bad things." Perhaps the point is that negative constitutionalism is appropriate for state governments but not for the national government. But that would ignore much of our history, in which most of the positive goods that government provides-e.g., public education, stable rules of contract and property, most public infrastructure-have been furnished by the states. See, e.g., The Federalist No. 46, at 243-45 (James Madison) (predicting that this would be the case).

174. See, e.g., Ernest A. Young, "Federal Preemption and State Autonomy," in Federal Preemption: States' Powers, National Interests, ed. Richard A. Epstein and Michael S. Greve (Washington, DC: AEI Press, 2007), 249, 255-57 (stressing the autonomy of states to make their own policy choices over libertarian conceptions of federalism that stress minimizing regulation).

175. See, e.g., Barber, "Defending Dual Federalism" (" $[A] n$ argument for dual federalism would have to occur in a national forum, and the expectations of that forum make it impossible to defend dual federalism.").

176. For a somewhat similar argument, stressing the need for a clear division of labor between national and state governments in order to promote market competition, see Greve, The Upside-Down Constitution, 6-78.

177. See Young, "Making Federalism Doctrine," 1836-40.

178. The Federalist No. 78, at 405 (Alexander Hamilton).

179. Herbert Wechsler, "Toward Neutral Principles of Constitutional Law," Harvard Law Review 73 (1959): 1, 15.

180. Vicki Jackson, "Federalism and the Uses and Limits of Law: Printz and Principle," Harvard Law Review 111 (1998): 2180, 2232.

181. See Felix Frankfurter, The Commerce Clause under Marshall, Taney, and Waite (Chapel Hill: University of North Carolina Press, 1937), 54.

182. See Larry Lessig, "Translating Federalism: United States $v$ Lopez," Supreme Court Review (1995): 125, 174 ("To the extent that results of a particular rule appear consistent, it is easier for the legal culture to view this rule as properly judicial, and its results as properly judicial. . . . To the extent, however, that the results appear inconsistent, this pedigree gets questioned; it becomes easier for observers to view these results as 
determined, or influenced, by factors external to the rule-in particular, factors considered political.").

183. Ibid.

184. Ibid., 174-75.

185. See, e.g., Siegel, "Distinguishing the 'Truly National' from the "Truly Local.",

186. Compare Gibbons v. Ogden, 22 U.S. (9 Wheat.) 1 (1824), with Willson v. Blackbird Creek Marsh Co., 27 U.S. (2 Pet.) 245 (1829).

187. Cooley v. Board of Wardens, 53 U.S. 299 (1852).

188. United States v. E. C. Knight Co., 156 U.S. 1 (1895).

189. Stafford v. Wallace, 258 U.S. 495 (1922).

190. Hammer v. Dagenhart, 247 U.S. 251 (1918).

191. See, e.g., Franklin Delano Roosevelt, "Fireside Chat on Reorganization of the Judiciary, March 9, 1937," reprinted in Ernest A. Young, The Supreme Court and the Constitutional Structure (Eagan, MN: Foundation Press, 2012), 284, 286.

192. See Cushman, Rethinking the New Deal Court, 42-43.

193. See, e.g., William E. Leuchtenburg, The Supreme Court Reborm: The Constitutional Revolution in the Age of Roosevelt (New York: Oxford University Press, 1995).

194. All models, of course, raise some line-drawing problems. But that is true throughout the law. Nonetheless, courts have been unwilling to abandon less-than-pellucid distinctions such as those between content-based and content-neutral restrictions on speech, fundamental and nonfundamental rights, and reasonable and unreasonable searches. The question is whether alternative models of federalism might offer somewhat more workable doctrinal tools than the failed jurisprudence of dual federalism.

195. 505 U.S. at 149. 